\title{
Heterogeneous feeding in benthic suspension feeders: the natural diet and grazing rate of the temperate gorgonian Paramuricea clavata (Cnidaria: Octocorallia) over a year cycle
}

\author{
Marta Ribes*, Rafel Coma, Josep-Maria Gili \\ Institut de Ciències del Mar (CSIC), Passeig Joan de Borbó s/n, E-08039 Barcelona, Spain
}

\begin{abstract}
Paramuricea clavata Risso, 1826 (Cnidaria: Octocorallia) is a characteristic species of Mediterranean benthic fauna. The natural diet and prey capture rate of the species were studied in the field at the Medes Islands (NW Mediterranean Sea) using continuous flow incubation chambers. In situ grazing rates on DOC, detrital POC, and pico-, nano- and microplankton were examined over 1 annual cycle. P. clavata capture nanoeukaryotes, phytoplankton and ciliates as well as detrital POC. Colonies

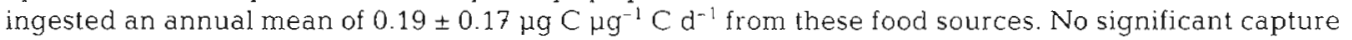
of DOC and picoplankton (heterotrophic bacteria, Prochlorococcus sp., Synechococcus sp. and picoeukaryotes) was observed. Carbon of detrital origin accounted for $86 \pm 14 \%$ of the total ingested carbon and showed a marked seasonal pattern in which winter and spring were the seasons with the highest ingestion rates. Ingestion of live POC also exhibited a marked seasonal pattern, with the highest values occurring in winter. The results show that $P$. clavata has a broad and heterogeneous diet that ranges from $3.8 \mu \mathrm{m}$ (nanoeukaryotes) to $700 \mu \mathrm{m}$ (copepods). Capture of detrital and live POC showed minimum values during the summer period, which supports the hypothesis that trophic limitations may underlie the summer regression in activity of the species. The results, together with evidence from previous studies, suggest that the capture of detrital POC may be a common and important feature among gorgonian species. It was calculated that the species daily captured $1-22 \%$ of diatoms, $1-9 \%$ of nanoeukaryotes, $1-26 \%$ of dinoflagellates, $2-99 \%$ of ciliates, and $2-10 \%$ of suspended detrital POC $\mathrm{m}^{-3}$ of the water adjacent to the bottom. The estimated capture rate of the species suggests that, in littoral ecosystems, grazing by macroinvertebrates on planktonic communities and suspended detrital POC should not be disregarded.
\end{abstract}

KEY WORDS: Suspension feeding - Natural diet - Grazing rate · Prey selection - Gorgonians Paramuricea clavata. Mediterranean Sea

\section{INTRODUCTION}

Microbial communities are the main contributors to pelagic planktonic communities in terms of biomass (Stockner \& Antia 1986) and production (Platt et al. 1983, Burkill et al. 1993). In consequence, much research has been conducted on the dynamics of these

·E-mail: mribes@icm.csic.es planktonic communities in the water column and their trophic interactions with other groups of plankters (Azam et al. 1983, Sherr \& Sherr 1991, Van Wambeke et al. 1996). In littoral ecosystems, little work has been conducted on the trophic interactions between microbial communities and benthic macroinvertebrates. However, recent studies have shown that the role of bacteria, protozoa and phytoplankton in the diet of benthic suspension feeders other than bivalves ap- 
pears to be stronger than previously thought fe.g. Petersen \& Riisgård 1992, Pile et al. 1996, 1997, Ribes et al. 1998a,b, 1999a).

Earlier studies about suspension feeding distinguished between those animals that capture small particles (i.e. microphagous) and those that capture zooplankton (i.e. macrophagous) (Jørgensen 1975 , Fauchald \& Jumars 1979). However, species that capture small particles also capture matter that ranges from detritus to small organisms such as bacteria (Reiswig 1975, Leonard 1989, Gaino et al. 1994). Similarly, species that feed on zooplankton can capture and assimilate a wide range of prey types from bacteria to phyto- and zooplankton (Coffroth 1984, Coma et al. 1994, Fabricius et al. 1995a). In general, the diet of benthic suspension feeders appears to be broader than previously thought.

Anthozoans are among the more conspicuous components in littoral benthic communities in temperate and tropical areas (e.g. True 1970, Loya 1972). Natural prey capture rates are available for a small number of hexacorallian and octocorallian species (e.g. Porter 1974, Lewis 1982, Johnson \& Sebens 1993, Coma et al. 1994, Sebens et al. 1996), but these studies have mainly focused on zooplankton as the principal prey type. Gorgonians present an interesting case because feeding studies have rarely shown the capture of zooplanktonic prey items (Kinzie 1973, Lasker 1981, Lasker et al. 1983), and alternative food sources such as suspended particulate matter (Lasker 1981), mucus produced by corals (Coffroth 1984), dissolved organic matter (Murdock 1978), and microplankton (Ribes et al. 1998a) have been proposed. In fact, significant capture of naturally occurring zooplankton prey in situ has only been shown in the Mediterranean species Paramuricea clavata Risso (Coma et al. 1994). Even in this species, the capture of zooplankton can only account for about $50 \%$ of its energetic requirements, suggesting that the role of other food sources should be explored (Coma et al. 1998a).

Paramuricea clavata is one of the most characteristic members of the benthic Mediterranean fauna, contributing the highest biomass (True 1970), and introducing structural complexity (Gili \& Ballesteros 1991) to some sublittoral communities. Previous studies have shown a marked seasonal pattern in the secondary production of the species, which is characterized by low activity during the summer period (i.e. non-reproductive investment, Coma et al. 1995a, b; low growth investment, Coma et al. 1998b; higher percentage of colonies with contracted polyps, Coma et al. 1994). In a previous study we suggested the hypothesis that low ingestion during the summer may underlie the low activity of the species during this time (Coma et al. 1998a). However, because the intake of zooplankton could not fulfill the energy requirements of this species, consideration of other potential food sources is crucial in order to support or reject the hypothesis.

The apparent lack of prey capture by gorgonians observed in some feeding studies (e.g. Kinzie 1973, Lasker 1981) might have been an artifact due to the methodology (i.e examination of gut contents), which underestimates small soft-bodied prey because they leave no recognizable remains. Therefore, in this study, we expand our observations on the feeding of Paramuricea clavata by examining grazing on dissolved organic carbon (DOC), detrital particulate organic carbon (detrital POC), and pico-, nano- and microplankton in in situ incubation chambers. We focus on 4 main questions: (1) what sestonic particles does the species feed on? (2) what is the grazing rate upon these particles? (3) is there a seasonal variation in grazing rate? and (4) what effect does predation by this species have on the plankton community?

\section{MATERIAL AND METHODS}

Feeding experiments were conducted in situ using continuous flow incubation chambers at the Medes Islands Marine Reserve (NW Mediterranean Sea, $\left.42^{\circ} 3^{\prime} \mathrm{N}, 3^{\circ} 13^{\prime} \mathrm{E}\right)$ from October 1995 to November 1996. Incubations were carried out in hemispherical UV-transparent Plexiglas chambers approximately 31 in volume. The chambers (1 experimental, with gorgonians, and 1 control) were placed on the sea bottom at $15 \mathrm{~m}$. The chambers had inlet and outlet apertures connected to a common piece of PVC tubing, so the system becomes closed. An electric pump at the outlet aperture forces water through the system at a speed of $1.2 \mathrm{~cm} \mathrm{~s}^{-1}$ during normal operation (this flow becomes turbulent inside the chambers). A submersible polarographic oxygen and temperature probe (Clarke-type oxygen probe, WTW EOT-196) was connected close to the pump propeller. Oxygen concentration and temperature were monitored in both chambers during the incubations. Whole Paramuricea clavata specimens between 12 and $15 \mathrm{~cm}$ in colony height were removed from the substratum, cleaned of macroepibionts, and attached to PVC posts (as in Ribes et al. 1998a). Colonies were kept in their natural environment with conspecifics until used in incubation experiments. At the beginning of each experiment, a $P$. clavata colony on a PVC post was placed on the base of the experimental chamber. Colonies were allowed to fully expand before the experiment started. During this period, the inlet and outlet apertures were not connected, and the system worked as an open-flow one. When the polyps were fully expanded, replicate water samples of $500 \mathrm{ml}$ were collected from the outlets of 
both chambers (initial water samples) and preserved for further analysis (see below). At this point, inlet and outlet apertures were connected and the system was subject to closed-flow. After $3 \mathrm{~h}$, replicate water samples of $500 \mathrm{ml}$ were again collected from both chambers (final water samples). All experiments were conducted between 09:00 and 14:00 h, and the activity rhythm of the incubated colony was recorded visually at $30 \mathrm{~min}$ intervals during the experiment. Usually the incubated colony and conspecifics remained with expanded polyps throughout the incubation. In the few cases when the polyps of the incubated colony contracted, the experiment was aborted. Grazing was calculated from decreases in prey concentration in the experimental chamber relative to the control chamber. Potential prey items included: prokaryotes (heterotrophic bacteria, Synechococcus sp., and Prochlorococcus sp.), eukaryotic pico- and nanoplankton, ciliates, phytoplankton (diatoms and dinoflagellates), DOC and detrital POC. Water volume used for the analysis of DOC, POC, prokaryotes, eukaryotic pico- and nanoplankton was previously screened by a $100 \mu \mathrm{m}$ net to avoid larger plankters. Five experiments were carried out each season, and therefore a total of 20 experiments were performed throughout the annual cycle.

To quantify heterotrophic bacteria, Prochlorococcus sp., Synechococcus sp., and pico- and nanoeukaryotes, we used flow cytometry. Two $\mathrm{ml}$ water samples from the incubation chambers were preserved for flow cytometry by standard protocols (Campbell et al. 1994), frozen in liquid nitrogen, and then stored at $-80^{\circ} \mathrm{C}$ or on dry ice. Samples were analyzed at the University of Hawaii Flow Cytometry Facility (Honolulu, HI, USA) using a Coulter EPICS 753 flow cytometer (Coulter Electronics Corporation, Hialeah, FL) equipped with two $5 \mathrm{~W}$ argon lasers and a Micro-Sampler-DeliverySystem. The flow cytometer was set up for UV $(220 \mathrm{~mW})$ and $488 \mathrm{~nm}(1 \mathrm{~W})$ colinear analysis. Hoechst 33342 (DNA-specific fluorochrome) was used to stain DNA according to Monger \& Landry (1993). Five parameters were collected in list mode and analyzed with custom-designed software (CYTOPC by Daniel Vaulot): red fluorescence (from chlorophyll a), orange fluorescence (from phycoerythrin), blue fluorescence (from DNA stained with Hoechst 33342), and forward- and right-angle light scatter signals (FALS and RALS). For statistical purposes sample size for analysis was chosen to provide more than 10000 events per sample, then $1 \mathrm{ml}$ of sample was analyzed for picoeukaryotes and nanoeukaryotes and $100 \mu$ for heterotrophic bacteria, Prochlorococcus sp. and Synechococcus sp.

Subsamples of $20 \mathrm{ml}$ were stained with DAPI and filtered through a $0.2 \mu \mathrm{m}$ (Nucleopore) filter to measure cell size (length and width) of heterotrophic bacteria and pico- and nanoeukaryotes. Epifluorescence microscopy was used to measure these cells and Synechococcus sp. For heterotrophic bacteria size estimation, over 100 cells were measured using image analysis software (Massana et al. 1997). For Synechococcus sp., and pico- and nanoeukaryote size estimation, cell length and width were measured with an ocular micrometer. Picoeukaryotes included naked flagellates smaller than $2 \mu \mathrm{m}$, and nanoeukaryotes included naked flagellates larger than $2 \mu \mathrm{m}$ as well as small dinoflagellates (unable to be distinguished with inverted microscope) and coccolithophores (unable to be counted with acid Lugol's) (see below). It was not possible to measure Prochlorococcus sp. due to the difficulty of observing the cells with epifluorescence microscopy, so a mean size for Prochlorococcus sp. of $0.7 \mu \mathrm{m}$ calculated in the Mediterranean by Vaulot et al. (1990) was used.

To quantify phytoplankton and ciliate cell numbers, $350 \mathrm{ml}$ water samples were preserved with acid Lugol's ( $1 \%$ final concentration). Subsamples of $100 \mathrm{ml}$ were settled in settling chambers, and major groups of nano- and microphytoplankton were quantified under an inverted microscope. The microscope was provided with a color CCD video camera connected to a video recorder. Images of the organisms for measurement were recorded on tape and digitized with a framegrabber. Size of the organisms was determined by image analysis software (NIH [National Institute of Health]-Image). For each subsample, 20 individuals of the most common groups were measured. The volumes were estimated from the length and width measurements, assuming ellipsoidal or cylindrical shapes (Edler 1979, Sebens \& Koehl 1984).

POC was measured by filtering a $60 \mathrm{ml}$ water sample on pre-combusted GF/F glass fiber filters. Filters were then frozen in liquid nitrogen and kept at $-80^{\circ} \mathrm{C}$ until analysis. Prior to analysis, filters were dried at $60^{\circ} \mathrm{C}$ for $24 \mathrm{~h}$ and exposed to $\mathrm{HCl}$ vapors for $48 \mathrm{~h}$ to destroy inorganic material. Then filters were dried again and analyzed with a $\mathrm{C}: \mathrm{H}: \mathrm{N}$ autoanalyser (Perkin-Elmer 240). POC measurements included both detrital and live carbon. Detrital organic carbon was estimated as the difference between total POC (C:H:N analysis) and total live carbon (estimated from cell counts and cell measurements).

For DOC, $20 \mathrm{ml}$ water samples were filtered through pre-combusted GF/F glass fiber filters. The filtered water was stored in glass tubes at $-20^{\circ} \mathrm{C}$ until analysis. Analysis was conducted by high-temperature catalytic oxidation with an autoanalyser (Shimadzu TOC-5000).

Depletion rates of the plankton were calculated assuming exponential growth and clearance of prey as described in Ribes et al. (1998a). The significance of predation on each kind of prey was tested by comparing growth rates of prey in control and experimental 
chambers with a 2-tailed Wilcoxon test (Sokal \& Rohlf 1995). Cell biovolume was calculated from length and width by approximation to the nearest geometric figures. Carbon content was then estimated from literature conversion factors as follows: heterotrophic bacteria, 0.22 pg $\mathrm{C} \mu \mathrm{m}^{-3}$ (Fry 1988); Prochlorococcus sp., 0.133 pg C $\mu \mathrm{m}^{-3}$ (Simon \& Azam 1989); Synechococcus sp., $0.357 \mathrm{pg} \mathrm{C} \mathrm{m}^{-3}$ (mean value of: Bjørnsen 1986, Kana \& Glibert 1987, Verity et al. 1992); pico- and nanoeukaryotes pg $\mathrm{C}=0.433 \times\left(\mu \mathrm{m}^{3}\right)^{0.863}$ (Verity et al. 1992); phytoplankton pg C cell ${ }^{-1}=0.109 \times\left(\mathrm{mm}^{3}\right)^{0991}$ (Montagnes et al. 1994); ciliates, $0.19 \mathrm{pg} \mathrm{C} \mathrm{mm}^{-3}$ (Putt \& Stoecker 1989).

Paramuricea clavata colonies were rinsed to remove salts and associated macrofauna, and dry weight was determined after drying at $90^{\circ} \mathrm{C}$ for $24 \mathrm{~h}$. In order to determine ash free dry weight (AFDW), the tissue and axis of the colonies were separated, and combusted separately at $450^{\circ} \mathrm{C}$ for $5 \mathrm{~h}$.

Multiple regression analysis was used to estimate the variance in filtration rates that could be explained by the factors monitored during each experiment: water temperature $\left({ }^{\circ} \mathrm{C}\right.$, recorded using a WTW (Wissenschaftlich Technische Werkstätten) oxygen electrode model

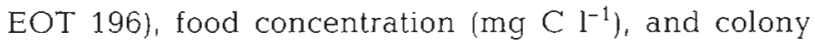
size (g AFDW). A backward stepwise procedure was used to exclude variables (Sokal \& Rohlf 1995). Variables were square root transformed when normality
(Kolmogorov-Smirnov test) and/or the heteroscedasticity (Levene's test) requirements were not fulfilled.

Daily ingestion rates were estimated based on the clearance rates (CR) calculated from the feeding experiments and the monthly mean prey concentration value for each prey type (Ribes et al. 1999b), and corrected by the activity rhythm (i.e. mean percentage of hours that the colonies have the polyps expanded) during each month of the year (Coma et al. 1994, authors' unpubl. data). Ingestion is expressed in terms of number of cells per polyp and time and in terms of carbon as a proportion of organic carbon weight of tissue (devoid of sclerites and skeletal axis) and time.

\section{RESULTS}

All sources of $\mathrm{POC}<100 \mu \mathrm{m}$, live carbon (i.e. recognizable cells), detrital carbon and DOC were considered as potential food sources. Live carbon included: prokaryotes, pico- and nanoeukaryotes, phytoplankton (diatoms and dinoflagellates) and ciliates. Fig. 1 shows the comparison between growth rates in the control and the experimental chambers for the different food sources (these data were collected in different seasons over the course of the year). Paramuricea clavata significantly captured nanoeukaryotes, diatoms, dinoflagellates and ciliates as well as detrital POC (Fig. 1). All these prey types decreased in abundance relative to the control in the presence of $P$ clavata. No significant decrease in prey items smaller than nanoeukaryotes (mean \pm SE: $3.8 \pm 1.4$ um) was observed.

Mean seasonal specific $C R\left(C R_{\text {AFD }}\right.$, ml swept clear $\mathrm{g}^{-1}$ AFDW $\mathrm{h}^{-1}$ ) for each prey type are showed in Fig. 2. There were significant differences in the $C R_{\text {AFDW }}$ between prey types (Table 1) due to the fact that Paramuricea clavata did not capture a significant proportion of prey items smaller than nanoeukaryotes (see above). However, $\mathrm{CR}_{\text {AFDw }}$ did not vary between nanoeukaryotes, phytoplankton and ciliates (Scheffé's post hoc test, $p>0.05) . C R_{A F D w}$ significantly varied among seasons (Table 1) due to the high $\mathrm{CR}_{\mathrm{AFDW}}$ values during winter (Scheffé's post hoc test, $\mathrm{p}<0.005)$. P. Clavata is a passive suspension feeder and, when the polyps are fully expanded, is not expected to be able to vary
Fig. 1. Net growth rates of prey (mean \pm SE) in the gorgonian chamber (in dotted bars) and in the control chamber (in empty bars) for each plankton group. Mean maximum length ( $\mathrm{mm}$ ) of each group (mean $\pm \mathrm{SE}$ ) is given at the bottom of the figure. Het B: heterotrophic bacteria, Pro: Prochlorococcus sp., Syn: Synechococcus sp., Pic: autotrophic picoeukaryotes, Nan: autotrophic nanoeukaryotes, Pen: pennate diatoms, Cen: centric diatoms, Din: dinoflagellates, Cil: ciliates, POC: detrital particulate organic carbon, DOC: dissolved organic carbon. The number of experiments ( $N$ ) throughout the year and the degree of significance from a 2 -tailed Wilcoxon test are also shown 

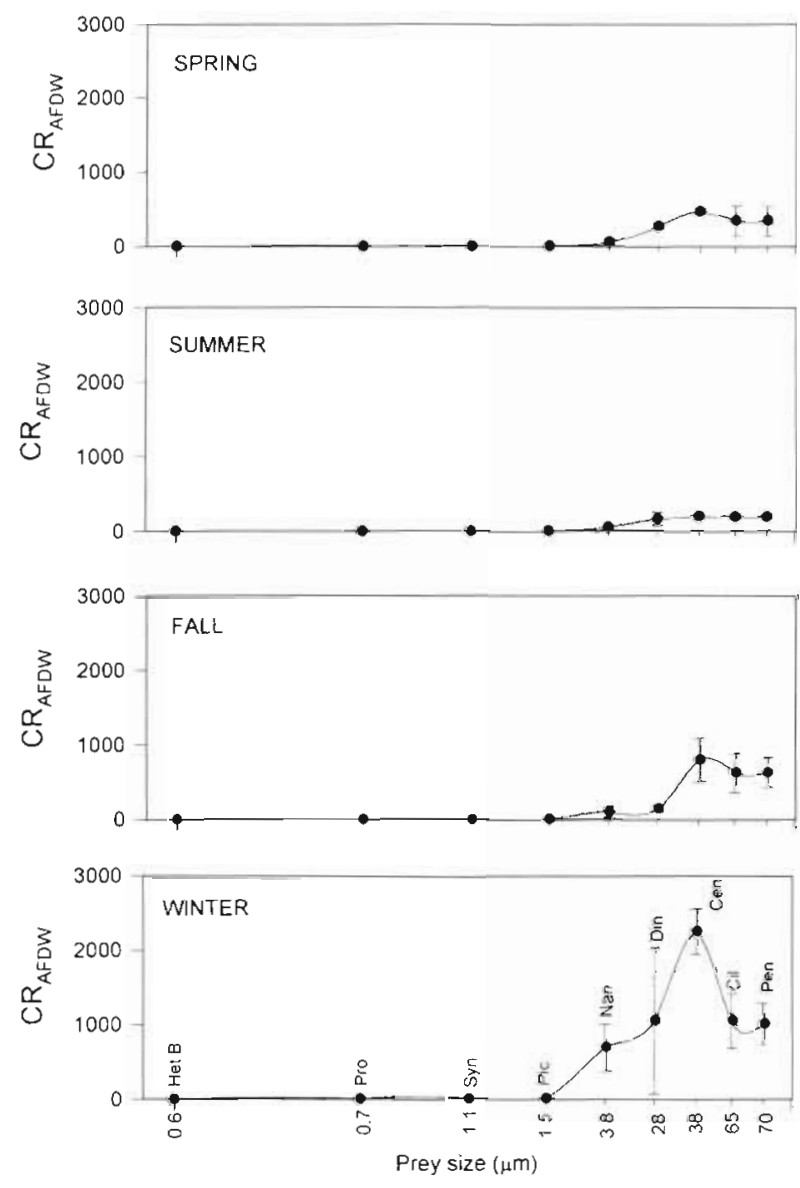

Fig. 2. Paramuricea clavata. Seasonal specific clearance rate $\left(C R_{A D F W}\right.$ ml swept clear $g^{-1}$ AFDW $h^{-1}$, mean \pm SE) as a function of prey size $(\mu \mathrm{m})$. Prey size in log scale. Abbreviations as

in Fig. 1. Five experiments were carried out per season

$\mathrm{CR}_{\mathrm{AFDW}}$. Thus, the effects of water temperature, food concentration and colony size on $\mathrm{CR}_{\text {AFDw }}$ over the year were tested (multiple regression analysis, Table 2). Variation in food concentration ( $\mathrm{mg} \mathrm{C}^{-1}$ ) explained $37 \%$ of variance in $\mathrm{CR}_{\mathrm{AFDW}}$ (backward stepwise procedure, $N=20$, adjusted $R^{2}=0.37, p<0.002$ ) and showed a marked pattern of $C R_{A F D W}$ increase with food con-

Table 1. Paramuricea clavata. Analysis of variance for specific clearance rate between captured prey types (i.e. nanoeukaryotes, diatoms, dinoflagellates and ciliates) and among seasons

\begin{tabular}{|lrrrrc|}
\hline Source & df & \multicolumn{1}{c}{ SS } & \multicolumn{1}{c}{ NIS } & \multicolumn{1}{c}{$F$} & P \\
\hline Prey type & 8 & 6904989 & 863123 & 5.7 & $<0.0001$ \\
Season & 3 & 51435442 & 1714514 & 11.32 & $<0.0001$ \\
Interaction & 24 & 6883629 & 336952 & 1.89 & 0.015 \\
Error & 96 & 14540300 & 151461 & & \\
\hline
\end{tabular}

centration increase (Fig. 3). Neither temperature nor colony size explained any significant amount of the

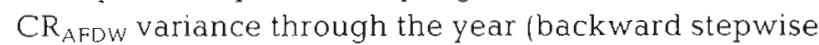
procedure, $p>0.3$ for both variables).

The seasonal variation of nano- and microplankton ingestion rate by the species is presented in Table 3. Throughout the year, the highest ingestion rate (in terms of cells) was for nanoeukaryotes. However, in biomass terms, the large cells of phytoplankton (diatoms and dinoflagellates) and ciliates accounted for the greatest contribution to ingestion. The highest values of ingestion were observed during winter (Table 3), mainly due to the high biomass values of phytoplankton during this time period (Ribes et al. 1999b).

The CRAFDw was always estimated for colonies with expanded polyps. However, Paramuricea clavata appears to exhibit a seasonal pattern of expansion and contraction (Coma et al. 1994, authors' unpubl. data). In order to calculate the annual amount of carbon ingested from predation on nanoeukaryotes, dinoflagellates, diatoms and ciliates, 3 factors were considered. First, the seasonal variation observed in $\mathrm{CR}_{\mathrm{AFDW}}$. Second, the monthly mean prey concentration value for each prey type (Ribes et al. 1999b). These 2 factors allowed an estimation of the monthly number of cells ingested per polyp per hour. The third factor was an estimation of the variation through the year of the number of hours with expanded polyps (activity rhythm; data from Coma et al. 1994, authors' unpubl. data), which allowed the calculation of the daily ingestion rate throughout the year. These calculations are presented in Table 4. According to these estimates, the species ingested between 31 and 794 cells polyp ${ }^{-1} \mathrm{~d}^{-1}$ (mean $\pm \mathrm{SD}, 276 \pm 225$ ) from feeding on nanoeukaryotes, dinoflagellates, diatoms and ciliates, depending on the season.

Annual mean $( \pm \mathrm{SD})$ carbon ingested by Paramuricea clavata was $0.19 \pm 0.17 \mu g \mathrm{C} \mu \mathrm{g}^{-1} \mathrm{C} \mathrm{d}^{-1}$ from the particles $<100 \mu \mathrm{m}$. The range of ingested carbon was from

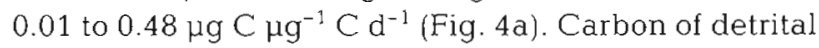

Table 2. Paramuricea clavata. Multiple regression analysis to estimate the variance in specific clearance rate explained by food concentration ( $\mathrm{mg} \mathrm{C} \mathrm{l}^{-1}$ ), colony size ( $\mathrm{g}$ AFDW) and water temperature $\left({ }^{\circ} \mathrm{C}\right) . \beta$ : standardized partial regression coefficient, Adj $R^{2}$ : adjusted $R^{2}, N=20$. ns: not significant

\begin{tabular}{|lcccc|}
\hline & $\mathrm{B}$ & $\beta$ & Adj $\mathrm{R}^{2}$ & $\mathrm{p}$ \\
\hline Food concentration & $632 \pm 456$ & 0.39 & 0.41 & 0.009 \\
Colony size & $-321 \pm 308$ & -0.28 & & \\
Temperature & $-32 \pm 81$ & -0.14 & & \\
Intercept & & & & ns \\
\hline
\end{tabular}




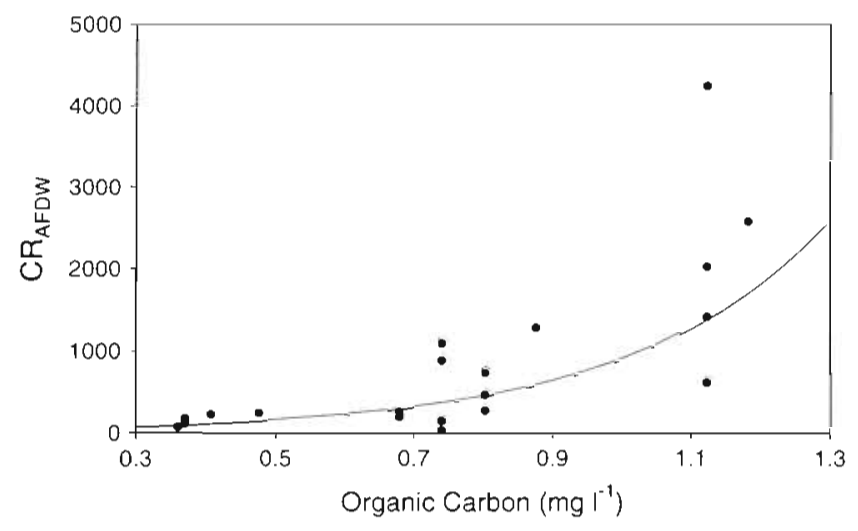

Fig. 3. Paramuricea clavata. Relationship between specific clearance rate $\left(\mathrm{CR}_{\mathrm{ADFW}} \mathrm{ml}\right.$ swept clear $\left.\mathrm{g}^{-1} \mathrm{AFDW} \mathrm{h}^{-1}\right)$ and total organic carbon

Table 3. Paramuricea clavata. Seasonal variation of nano- and microplankton ingestion rate (mean \pm SE) by $P$. clavata. Data expressed in number of cells and in carbon units

\begin{tabular}{|lccrr|}
\hline Prey & Summer & Spring & Fall & Winter \\
\hline (Cells polyp $^{-1} \mathbf{h}^{-\mathbf{1}}$ ) & & & & \\
Nanoeukaryotes & $29 \pm 14$ & $26 \pm 12$ & $19 \pm 15$ & $43 \pm 33$ \\
Diatoms & $0.1 \pm 0.04$ & $3 \pm 1$ & $0.04 \pm 0.02$ & $1 \pm 0.4$ \\
Dinoflagellates & $0.2 \pm 0.1$ & $1 \pm 0.1$ & $0.2 \pm 0.04$ & $0.3 \pm 0.2$ \\
Ciliates & $0.04 \pm 0.02$ & $0.1 \pm 0.04$ & $0.1 \pm 0.04$ & $0.3 \pm 0.1$ \\
& & & & \\
(pg C $\mathbf{~ p g ~ C ~ t i s s u e ~}^{-\mathbf{1}} \mathbf{h}^{-\mathbf{1}}$ ) & & & \\
Nanoeukaryotes & $214 \pm 104$ & $234 \pm 114$ & $276 \pm 230$ & $829 \pm 464$ \\
Diatoms & $117 \pm 65$ & $225 \pm 113$ & $362 \pm 115$ & $1377 \pm 688$ \\
Dinoflagellates & $63 \pm 33$ & $56 \pm 25$ & $39 \pm 15$ & $33 \pm 27$ \\
Ciliates & $221 \pm 115$ & $207 \pm 98$ & $210 \pm 96$ & $195 \pm 115$ \\
\hline
\end{tabular}

origin accounted for $86 \pm 14 \%$ of the total ingested carbon and showed a marked seasonal pattern in which winter and spring ingestion rates were the highest (Fig. 4a). Ingestion of live carbon also exhibited a marked seasonal pattern, with the highest values occurring during winter (Fig. 4b). Phytoplankton (diatoms and dinoflagellates) was the main contributor to the live particle diet, accounting for over $48 \pm 6 \%$ of the total ingested live carbon

Table 5 shows the contribution of carbon ingested from detrital POC, nanoeukaryotes, phytoplankton, and ciliates observed in this study and that of zooplankton prey items previously reported (Coma et al. 1994). In carbon units, ingestion of detrital POC was about half of that of the zooplankton $(46 \pm 39 \%$, mean $\pm \mathrm{SD}$; Table 5). As previously observed, the contribution of detrital POC exhibited a marked seasonal pattern, with the highest values observed during winter and spring when it accounted for $73 \pm 28 \%$ of the zooplankton ingestion (mean of \% detritus/zooplankton from December to June, Table 5). The ingestion of nanoeukaryotes, phytoplankton, and ciliates accounted for a mean value of $2 \pm 2 \%$ of the zooplankton ingestion.

\section{DISCUSSION}

The study, carried out seasonally over an annual cycle, covered the entire natural range of potential prey items for Paramuricea clavata, apart from zooplankton, which included

Table 4. Paramuricea clavata daily capture rates (mean $\pm \mathrm{SE}$ ) estimated from the ingestion rate and the rhythm of activity $\left(\mathrm{h} \mathrm{d}^{-1}\right.$ : daily number of hours with expanded polyps). Nan: autotrophic nanoeukaryotes, Dia: diatoms, Din: dinoflagellates, Cil: ciliates

\begin{tabular}{|c|c|c|c|c|c|c|}
\hline Month & Nan & $\begin{array}{l}\text { Dia } \\
\text { [cells }\end{array}$ & $\begin{array}{l}\text { Din } \\
\left.o^{-1} h^{-1}\right)\end{array}$ & Cil & $\begin{array}{l}\text { Rhythm } \\
\left(\text { h d }^{-1}\right)\end{array}$ & $\begin{array}{c}\text { Total } \\
\left.\text { (cells polyp }{ }^{-1} \mathrm{~d}^{-1}\right)\end{array}$ \\
\hline Dec & $78 \pm 54$ & $0.49 \pm 0.26$ & $0.29 \pm 0.13$ & $0.30 \pm 0.03$ & 10 & $794 \pm 351$ \\
\hline $\operatorname{Jan}$ & $38 \pm 33$ & $0.59 \pm 0.31$ & $0.43 \pm 0.19$ & $0.32 \pm 0.03$ & 8.2 & $325 \pm 158$ \\
\hline Feb & $33 \pm 26$ & $1.16 \pm 0.62$ & $0.44 \pm 0.20$ & $0.60 \pm 0.06$ & 9.4 & $332 \pm 156$ \\
\hline Mar & $13 \pm 13$ & $1.51 \pm 0.66$ & $0.23 \pm 0.08$ & $0.04 \pm 0.01$ & 8.9 & $135 \pm 66$ \\
\hline Apr & $22 \pm 17$ & $0.84 \pm 0.36$ & $0.21 \pm 0.07$ & $0.04 \pm 0.01$ & 8.9 & $208 \pm 91$ \\
\hline May & $62 \pm 40$ & $1.18 \pm 0.51$ & $0.41 \pm 0.14$ & $0.04 \pm 0.01$ & 7.4 & $471 \pm 191$ \\
\hline Jun & $55 \pm 12$ & $1.33 \pm 0.26$ & $0.19 \pm 0.04$ & $0.02 \pm 0.003$ & 8.8 & $495 \pm 91$ \\
\hline Jul & $18 \pm 5$ & $0.02 \pm 0.01$ & $0.14 \pm 0.03$ & $0.03 \pm 0.004$ & 1.7 & $31 \pm 6$ \\
\hline Aug & $21 \pm 6$ & $0.01 \pm 0.002$ & $0.10 \pm 0.02$ & $0.01 \pm 0.002$ & 3.1 & $65 \pm 13$ \\
\hline Sep & $20 \pm 16$ & $0.04 \pm 0.01$ & $0.09 \pm 0.07$ & $0.10 \pm 0.01$ & 7.7 & $158 \pm 83$ \\
\hline Oct & $20 \pm 15$ & $0.04 \pm 0.01$ & $0.08 \pm 0.07$ & $0.07 \pm 0.01$ & 8.6 & $176 \pm 90$ \\
\hline Nov & $21 \pm 14$ & $0.004 \pm 0.001$ & $0.06 \pm 0.05$ & $0.05 \pm 0.01$ & 6 & $125 \pm 62$ \\
\hline
\end{tabular}



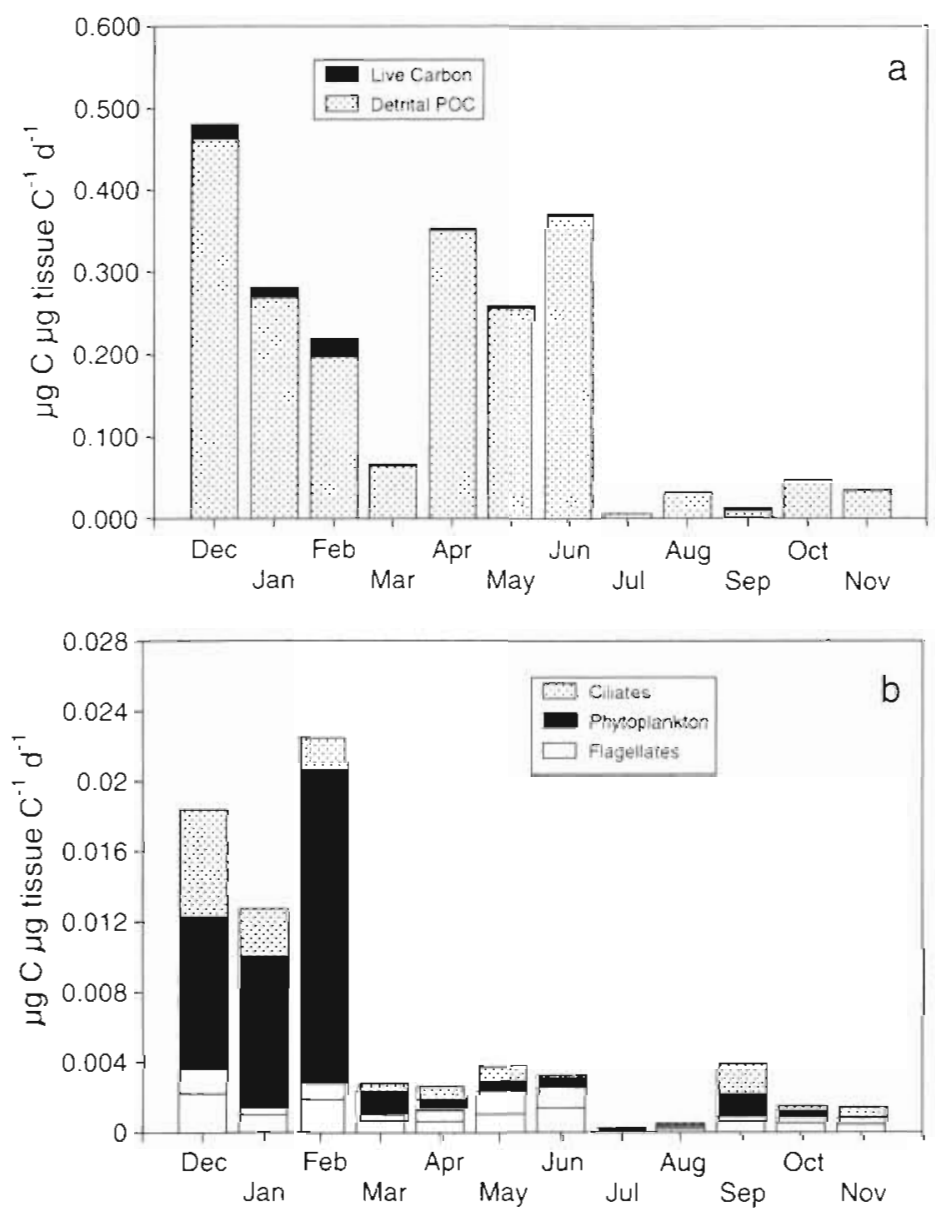

Fig. 4. Paramuricea clavata. Monthly estimate of the total ingested organic carbon ( $\mu \mathrm{g} \mathrm{C} \mathrm{gg}^{-1}$ tissue $\mathrm{C} \mathrm{h}^{-1}$ ) over an annual cycle. (a) Tatal amount divided in the 2 main food sources: live carbon and carbon from detrital origin. (b) Composition of the ingested live carbon. Flagellates include autotrophic and heterotrophic nanoeukaryotes and phytoplankton include diatoms and dinoflagellates

Table 5. Paramuricea clavata monthly capture rates of live and detrital particles $<100 \mu \mathrm{m}\left[\left(\mu \mathrm{g} \mathrm{C}\right.\right.$ polyp $\left.{ }^{-1} \mathrm{~d}^{-1}\right) \times 100$, mean $\pm \mathrm{SE}$ ], and zooplankton (data from Coma et al. 1994). Det: detritus, Zoop: zooplankton

\begin{tabular}{|lccccc|}
\hline Month & Live $<100 \mu \mathrm{m}$ & Det $<100 \mu \mathrm{m}$ & Zoop & \% Det/Zoop & \% Live/Zoop \\
\hline Dec & $1.84 \pm 0.97$ & $48.1 \pm 20.4$ & 50 & $97 \pm 49$ & $3.7 \pm 1.9$ \\
Jan & $1.27 \pm 0.65$ & $28.1 \pm 14.6$ & 29 & $98 \pm 52$ & $4.5 \pm 2.3$ \\
Feb & $2.25 \pm 1.31$ & $21.8 \pm 16.1$ & 37 & $59 \pm 32$ & $6.0 \pm 3.5$ \\
Mar & $2.28 \pm 0.22$ & $6.6 \pm 3.2$ & 19 & $35 \pm 17$ & $1.4 \pm 1.2$ \\
Apr & $2.26 \pm 0.24$ & $35.2 \pm 18.4$ & 44 & $80 \pm 42$ & $0.6 \pm 0.5$ \\
May & $0.38 \pm 0.12$ & $25.8 \pm 13.3$ & 62 & $41 \pm 21$ & $0.6 \pm 0.3$ \\
Jun & $0.32 \pm 0.13$ & $37.0 \pm 6.2$ & 38 & $98 \pm 16$ & $0.9 \pm 0.3$ \\
Jul & $0.03 \pm 0.01$ & $0.6 \pm 0.1$ & 25 & $2 \pm 0.3$ & $0.1 \pm 0.03$ \\
Aug & $0.06 \pm 0.01$ & $3.1 \pm 0.5$ & 30 & $10 \pm 2$ & $0.2 \pm 0.1$ \\
Sep & $0.39 \pm 0.18$ & $1.3 \pm 0.7$ & 26 & $5 \pm 2$ & $1.5 \pm 0.7$ \\
Oct & $0.15 \pm 0.12$ & $4.6 \pm 3.1$ & 29 & $16 \pm 10$ & $0.5 \pm 0.3$ \\
Nov & $0.15 \pm 0.11$ & $3.4 \pm 2.2$ & 63 & $5 \pm 3$ & $0.2 \pm 0.1$ \\
Mean & 0.62 & 18.0 & 38 & 46 & 2 \\
SE & 0.22 & 4.8 & 4 & 11 & 0.6 \\
\hline
\end{tabular}

DOC, detrital POC, and pico-, nano-, and microplankton. The results have shown that the species regularly feeds on detrital POC, nanoeukaryotes, phytoplankton and ciliates, but not on items of a size smaller than $3 \mu \mathrm{m}$, nor does it take up DOC. In a previous study we observed that nauplii, copepod eggs, other invertebrate larvae, and other prey items between 100 and $200 \mu \mathrm{m}$ accounted for the bulk of the zooplankton prey captured by the species, although adult copepods up to $600-700 \mu \mathrm{m}$ were also captured (Coma et al. 1994). Therefore, the range of prey items captured by $P$. clavata appears to be between $3.8 \mu \mathrm{m}$ (nanoeukaryotes) and $700 \mu \mathrm{m}$ (adult copepods). This broad size range of food sources is similar to that recently obtained through both gut content analysis and in situ feeding experiments on tropical gorgonians, which have been observed to capture prey items from about $5 \mu \mathrm{m}$ to zooplankton about $700 \mu \mathrm{m}$ (Ribes et al. 1998a). The results are also consistent with previous gut contents studies (e.g. Leversee 1976, Lasker 1981, Lasker et al. 1983) as well as with feeding experiments carried out in the laboratory (Sorokin 1991). Thus, detrital POC, nanoplankton, and microplankton may constitute a regular feeding source for many gorgonian species. In general, benthic suspension feeders face a wide spectrum of potential prey, including DOC, detrital POC and live POC (bacteria, protozoa, phytoplankton and zooplankton). Even those cnidarian species that appear to rely almost exclusively on zooplankton exhibit diet variety (Sebens \& Koehl 1984, Barange \& Gili 1988). Although in some species from other groups a single prey type can provide most of the energetic requirements (Klumpp 1984, Asmus \& Asmus 1991), it appears that a wide and heterogeneous diet is a common feeding strategy in littoral benthic suspension feeders (e.g. Stuart \& Klumpp 1984, Coma et al. 1994, 1995c, Ribes et al, 1998b, 1999).

Prey capture by Paramuricea clavata appears to be mainly carried out through tentacular feeding, using some of the capture mechanisms described by aerosol filtration theory (Rubenstein \& Koehl 1977). As in scleractinian corals (Sebens et al. 1996), direct interception is likely to be the main mode of nano- and microplankton capture. The use of very developed epidermal cilia present in tentacles and around 
the mouth of anthozoan polyps (Fautin \& Mariscal 1991) could be an essential mechanism for both efficient capture of small food particles and delivery of the prey to the coelenteron. The capture of small organisms and particles is also facilitated by a morphologic characteristic of the octocorals: the siphonoglyph. The siphonoglyph drives a constant water current through the gastrovascular cavity mainly for respiratory and excretory reasons (Hyman 1940), but it also allows particles to come in and out of the gastrovascular cavity (Bouillon 1995). Pratt (1906) suggested that the constant flow through the gastrovascular cavity may facilitate the capture of microorganisms by the mesenterial filaments. The use of mucus is another mechanism of capturing suspended detrital and live particles (Coffroth 1984). In areas where an important number of species produce mucus, such as in tropical areas, mucus ingestion may allow colonies to capture significant amounts of organisms smaller than $3 \mu \mathrm{m}$, such as bacteria.

An important component of Paramuricea clavata's diet was detrital POC. The importance of detrital POC as a food source for benthic organisms has long been recognized (e.g. Tenore et al. 1982), and detrital POC utilization has been reported for active suspension feeders (e.g. Charles et al. 1996). In cnidarians, there is little direct evidence of detrital POC utilization (Coma et al. 1995c). However, the results of experimental studies carried out with Artemia cysts and sephadex beads (e.g. Leversee 1976, Lasker 1981, Lasker et al. 1983) show that gorgonians are able to capture nonmotile prey items and to incorporate POC (Coffroth 1984). Our results, together with those experimental studies, suggest that the capture of detrital POC may be a common feature among gorgonian species. Nevertheless, it is difficult to quantify the importance of detrital POC as a food source due to its broad range of nutritive value, mainly a function of its origin (Tenore et al. 1982).

The annual capture rate of live POC estimated for Paramuricea clavata (6.2 ng C polyp $\left.\mathrm{p}^{-1} \mathrm{~d}^{-1}\right)$ was similar to that estimated for the tropical gorgonian Plexaura flexuosa ( $4.0 \mathrm{ng} \mathrm{C}$ polyp $\mathrm{p}^{-1} \mathrm{~d}^{-1}$ ) using the same methodology (Ribes et al. 1998a). However, P. clavata exhibited a highly variable capture rate (from 1.4 to $17.9 \mathrm{ng}$ C polyp ${ }^{-1} \mathrm{~d}^{-1}$, summer and winter respectively), mainly due to the variation of POC composition throughout the year (i.e. live carbon is dominated by microplankton from December to March, while from April to November, pico and nanoplankton are dominant; Ribes et al. 1999b)

Table 5 shows the contribution of carbon ingested by Paramuricea clavata from a wide spectrum of food types. If capture rates were corrected by the assimilation efficiency (75\% for live carbon, Zamer 1986, 30\% for detrital POC, Wotton 1992), then live POC intake was $4.6 \mathrm{ng} C$ polyp ${ }^{-1} \mathrm{~d}^{-1}$, and detrital POC intake was $54 \mathrm{ng} C$ polyp $\mathrm{p}^{-1} \mathrm{~d}^{-1}$. Therefore, detrital POC intake was about 12 times higher than that of live POC. However, because experiments were always conducted at low flow speed $\left(1.2 \mathrm{~cm} \mathrm{~s}^{-1}\right)$, and due to the dependence of particle intake on flow speed (e.g. Dai \& Lin 1993, Fabricius et al. 1995b), the estimated capture rates would appear to be highly conservative. Fabricius et al. (1995b) assessed the effect of flow speed on phytoplankton capture rate of the soft coral Dendronephthya hemprichi. These authors observed that the phytoplankton capture rate at 8 to $10 \mathrm{~cm} \mathrm{~s}^{-1}$ was about 5 times higher than that at 4 to $6 \mathrm{~cm} \mathrm{~s}^{-1}$. Assuming a flow effect on particle intake for $P$. clavata similar to that of the soft coral $D$. hemprichi, and because the studied area is subjected to an average current speed of $10.4 \mathrm{~cm} \mathrm{~s}^{-1}$ (Coma unpubl. data), a rough approximation could be obtained by multiplying the calculated feeding rates by 5 . Then, the assimilation of detrital POC would be similar to that of the zooplankton (i.e. detrital POC $270 \mathrm{~g} \mathrm{C}_{\text {polyp }}{ }^{-1} \mathrm{~d}^{-1}$ vs zooplankton $275 \mathrm{ng}$ C polyp ${ }^{-1} \mathrm{~d}^{-1}$; Coma et al. 1998a). The assimilation of live POC would account for $21 \mathrm{ng} C$ polyp $\mathrm{p}^{-1} \mathrm{~d}^{-1}$. Under this assumption, feeding on these different food sources would cover the energy needs of the species (566 ng C polyp ${ }^{-1} \mathrm{~d}^{-1}$; see Coma et al. 1998a) by means of a similar contribution of detrital POC and zooplankton (about $48 \%$ each). The assimilation of live POC would contribute less than $4 \%$ of the total assimilated carbon.

Our results suggest that live POC contributes a small portion of the diet of Paramuricea clavata. We observed a similarly low live POC contribution to the diet of the tropical gorgonian Plexaura flexuosa $4.0 \mathrm{ng}$ C polyp ${ }^{-1} \mathrm{~d}^{-1}$; Ribes et al. 1998a). Using the gut fluorescence method, a similar feeding rate on phytoplankton for the soft coral Dendronephthya hemprichi has been estimated ( $9 \mathrm{ng} \mathrm{C}$ polyp ${ }^{-1} \mathrm{~d}^{-1}$ at 4 to $6 \mathrm{~cm} \mathrm{~s}^{-1}$; Fabricius et al. 1995a,b and Erratum). Under the above assumption, feeding of $P$. clavata on live POC would account for about $6 \%$ of the respiratory needs (respiration rate from Coma et al. 1998a). These results are within the values reported for several symbiotic and asymbiotic tropical alcyonacean and gorgonacean species in the laboratory, using radioactively labeled prey (Sorokin 1991). Feeding rates for those species on algae accounted for 0.1 to $6 \%$ of respiratory needs and on ciliates for 0.4 to $9.1 \%$. Therefore, our results together with these previous studies, suggest that live POC contributes a small portion of the diet of octocorals. These results contrast with the high feeding rates on phytoplankton estimated for $D$. hemprichi by in situ measurements of chlorophyll depletion, which accounted for $730 \mathrm{ng} \mathrm{C}$ polyp $\mathrm{p}^{-1} \mathrm{~d}^{-1}$ at $3.8 \mathrm{~cm} \mathrm{~s}^{-1}$ 
(Fabricius et al. 1998). Feeding on algae has also been reported to cover an important fraction of the respiratory needs in 1 of the 22 octocoral species (i.e. $34 \%$ in Mopsella aurantia) examined by Sorokin (1991). Therefore, algal feeding appears to be a potentially important, but variable, dietary factor among octocoral species.

The present study shows a marked seasonality in prey capture. Detrital POC capture rates were high during winter and spring. The highest values of live particle intake were observed during the winter period. This seasonal variation reflected the abundance of $\mathrm{POC}$ in the water column and is similar to that observed with the capture of zooplankton (Coma et a). 1994). In a previous study we suggested that the low zooplankton ingestion during the summer may underlie the low activity of the species during this time period (Coma et al. 1998a). The present study has shown that the seasonal patterns of abundance and capture of detrital and live POC also exhibit minimum values during the summer period. Thus, the results support the hypothesis that trophic energetic limitations may underlie the summer regression in activity of the species.

\section{Heterogeneous diet from an optimality approach}

It has long been postulated that most suspension feeders are non-selective (Jørgensen 1966), and that diet is primarily controlled by structural constraints (Rubenstein \& Koehl 1977). If this is so, then, within morphological limitations, the composition of the ingested material should be similar to that of suspended material in the surrounding water. However, most feeding studies have been carried out with restricted or artificial diets (e.g. Leversee 1976, Lasker 1981), or through gut contents analysis, which potentially underestimates small soft-bodied organisms because they leave no recognizable remains (e.g. Coma et al. 1994). Those studies do not reveal which organic matter fractions are used as food sources (but see Ribes et al. 1998a). The results of the present study and those from a previous study of gut contents (Coma et al. 1994) indicate that the diet of the gorgonian Paramuricea clavata is highly heterogeneous. The broad and varied diet of this species is also observed in other benthic suspension feeder groups such as sponges (Reiswig 1971, Ribes et al. 1999a), ascidians (Randløv \& Riisgård 1979, Klumpp 1984, Ribes et al. 1998b) and hydrozoans (Coma et al. 1995c, Gili et al. 1998).

Benthic suspension feeders live in an environment where potential prey are diluted and patchily distributed. Therefore, resources are heterogeneous and vary stochastically. It has been pointed out that the optimal foraging theory developed for plankton organisms (Lehmann 1976) broadly applies to benthic organisms and in particular to suspension feeders (Hughes 1980 , Okamura 1990). An important strategy of benthic suspension feeders is that they invest little effort in food capture. The cost is virtually nil in passive suspension feeders while pumping in some active suspension feeders has been estimated to account for about $4 \%$ of the energy demand (Riisgård \& Larsen 1996). In the framework of the optimal foraging theory (Stephens \& Krebs 1986), species that expend low levels of energy in foraging are considered as ecologically highly successful (Hughes 1979, Gili \& Coma 1998).

In heterogeneous and stochastic environments, mobile consumers can optimize ingestion rates by moving to new food patches. Some have the capacity to change prey type by changing their capture technique (Akre \& Johnson 1979). These strategies can maximize the profitability of the search and capture activities (Stephens \& Krebs 1986). Sessile consumers, such as the majority of benthic invertebrates, must use a different way of optimizing prey capture. Some sessile suspension feeders can alternate feeding techniques (see Okamura 1990 for review). Although feeding mode and success may change with the hydrodynamic regime (e.g. LaBarbera 1984), many benthic suspension feeders (especially cnidarians) have a highly reduced capacity to modify their feeding techniques. Thus, the heterogeneity in their diet may be particularly significant in allowing them to opportunistically exploit a wide range of resources which are highly variable both in space and time. The heterogeneity observed in the diet of several benthic suspension feeder species from different taxa may represent one of the most important characteristics that has allowed the success of suspension feeding in benthic invertebrates. In this sense, as pointed out by Okamura (1990), the foraging strategy followed by sessile consumers appears to differ fundamentally from that described for more traditionally studied mobile consumers such as the zooplankton (DeMott 1990). However, even among zooplankton in which selectivity has been observed (e.g. Starkweather \& Bogdan 1980 , Huntley et al. 1986, DeMott 1990), analysis of gut contents and fecal pellets provides evidence of rather broad diets (Turner 1984, Hart 1987, Purcell \& Madin 1991)

\section{Predation impact on the microbial community}

Density of Paramuricea clavata at the study site was 32 colonies $\mathrm{m}^{-2}$, with a mean height of $30 \mathrm{~cm}$ (study area: $10 \mathrm{~m}^{2}$ ). Coma et al. (1994) estimated a total of 159916 polyps $\mathrm{m}^{-2}$ for the area, based on the colony 
density, polyp density and demographic structure of the P. clavata population (Coma 1994). At the estimated capture rates, $P$. clavata polyps captured 4-1870 $\times 10^{3}$ diatoms, $5-125 \times 10^{6}$ nanoeukaryotes, $4-70 \times$ $10^{4}$ dinoflagellates, and $6-900 \times 10^{3}$ ciliates $\mathrm{m}^{-2} \mathrm{~d}^{-1}$, depending on the time of the year (Table 6). Overall, this capture rate was the equivalent of removing between 76 and 15708 (mean \pm SD, $2782 \pm 4915$ ) $\mu \mathrm{g} \mathrm{C}$ $\mathrm{m}^{-2} \mathrm{~d}^{-1}$ from live POC, and between 959 and 76920 (mean $\pm \mathrm{SD}, 28732 \pm 26700) \mu \mathrm{g} \mathrm{C} \mathrm{m} \mathrm{Cm}^{-2} \mathrm{~d}^{-1}$ from suspended detrital POC. Ambient concentrations of these microorganisms over the annual cycle are 300-95300 diatoms $\mathrm{l}^{-1}, 380-3270$ naneukaryotes $\mathrm{ml}^{-1}$, 1780-4590 dinoflagellates $\mathrm{l}^{-1}$, and 170-920 ciliates $\mathrm{l}^{-1}$. and $19-813 \mu \mathrm{g}$ detrital POC $\mathrm{l}^{-1}$. This predation rate implies that the $P$. clavata population is daily removing $1-22 \%$ of diatoms, $1-9 \%$ of nanoeukaryotes, $1-26 \%$ of the dinoflagellates, $2-99 \%$ of ciliates, and $2-10 \%$ of suspended detrital POC $\mathrm{m}^{-3}$ of the water adjacent to the bottom. These estimates appear to be highly conservative because particle intake depends on flow speed in octocorals (see above). It has been shown that particle intake rate increases initially with flow speed, reaches a peak value and then decreases with increasing flow speed. Optimal feeding rates range from 8 to $15-18 \mathrm{~cm} \mathrm{~s}^{-1}$, depending on the species (Dai \& Lin 1993, Fabricius et al. 1995b). Thus, the POC intake rate estimated in this study most probably represents a minimum value, because experiments were conducted at a low flow speed.

Since gorgonians are among the more conspicuous components in littoral benthic communities in tropical (Bayer 1961, Tursch \& Tursch 1982) and temperate seas (Pérès \& Picard 1964, Gili \& Ros 1985), the estimated impact of Paramuricea clavata, and likely of other gorgonian species, on the microbial assemblages and suspended detrital POC appears to be significant. Furthermore, several recent studies on different macroinvertebrate groups such as sponges (Pile et al. 1996, 1997, Ribes et al. 1999a), ascidians (Klumpp 1984, Petersen \& Riisgård 1992, Ribes et al. 1998b), polychaetes (Riisgård et al. 1996, Vedel 1998) and hydroids

Table 6. Paramuricea clavata. Estimated size and variability of the ecological predatory impact of a $1 \mathrm{~m}^{2}$ population (at 32 colonies $\mathrm{m}^{-2}$ ) in number of cells and in carbon units (mean \pm SE, see Table 4 for error terms of the number of cells captured). Percentage $(\%)$ of cleared cells estimated using (a) prey and (b) detrital POC abundances from Ribes et al. (in press). Abbreviations as in Table 4

\begin{tabular}{|c|c|c|c|c|c|c|c|c|c|c|c|c|c|}
\hline \multicolumn{14}{|c|}{ (a) Predatory impact using prey abundance } \\
\hline Month & Nan & Dia & Din & Cil & Nan & Dia & Din & Cil & Nan & Dia & Din & Cil & Total \\
\hline Dec & $1.25 \times 10^{8}$ & $7.80 \times 10^{5}$ & $4.57 \times 10^{5}$ & $4.79 \times 10^{5}$ & 9 & 22 & 26 & 99 & 594 & 5907 & 15 & 1195 & $7711 \pm 3411$ \\
\hline $\operatorname{Jan}$ & $5.02 \times 10^{7}$ & $7.72 \times 10^{5}$ & $5.69 \times 10^{5}$ & $4.16 \times 10^{5}$ & 7 & 18 & 21 & 85 & 238 & 5842 & 19 & 1039 & $7138 \pm 3464$ \\
\hline Feb & $4.99 \times 10^{7}$ & $1.74 \times 10^{6}$ & $6.63 \times 10^{5}$ & $9.00 \times 10^{5}$ & 9 & 20 & 24 & 98 & 236 & 13202 & 22 & 2247 & $15708 \pm 7389$ \\
\hline Mar & $1.91 \times 10^{7}$ & $2.15 \times 10^{6}$ & $3.24 \times 10^{5}$ & $5.33 \times 10^{4}$ & 3 & 10 & 13 & 22 & 114 & 121 & 18 & 12 & $266 \pm 130$ \\
\hline Apr & $3.17 \times 10^{7}$ & $1.19 \times 10^{6}$ & $2.95 \times 10^{5}$ & $6.33 \times 10^{4}$ & 3 & 10 & 13 & 22 & 190 & 67 & 16 & 15 & $288 \pm 127$ \\
\hline May & $7.34 \times 10^{7}$ & $1.40 \times 10^{6}$ & $4.88 \times 10^{5}$ & $4.89 \times 10^{4}$ & 2 & 9 & 11 & 18 & 440 & 79 & 27 & 11 & $557 \pm 226$ \\
\hline Jun & $7.70 \times 10^{7}$ & $1.87 \times 10^{6}$ & $2.62 \times 10^{5}$ & $3.26 \times 10^{4}$ & 3 & 7 & 7 & 11 & 499 & 243 & 18 & 156 & $917 \pm 169$ \\
\hline Jul & $4.93 \times 10^{6}$ & $6.42 \times 10^{3}$ & $3.74 \times 10^{4}$ & $8.53 \times 10^{3}$ & 1 & 1 & 1 & 2 & 32 & 1 & 3 & 41 & $76 \pm 15$ \\
\hline Aug & $1.03 \times 10^{7}$ & $4.72 \times 10^{3}$ & $5.01 \times 10^{4}$ & $6.20 \times 10^{3}$ & 1 & 3 & 3 & 4 & 67 & 1 & 4 & 30 & $101 \pm 20$ \\
\hline Sep & $2.49 \times 10^{7}$ & $5.23 \times 10^{4}$ & $1.05 \times 10^{5}$ & $1.19 \times 10^{5}$ & 2 & 10 & 3 & 19 & 143 & 21 & 5 & 69 & $237 \pm 125$ \\
\hline Oct & $2.79 \times 10^{7}$ & $5.52 \times 10^{4}$ & $1.11 \times 10^{5}$ & $9.25 \times 10^{4}$ & 3 & 11 & 4 & 22 & 160 & 22 & 5 & 53 & $241 \pm 123$ \\
\hline Nov & $1.98 \times 10^{7}$ & $4.18 \times 10^{3}$ & $5.65 \times 10^{4}$ & $4.90 \times 10^{4}$ & 2 & 8 & 3 & 15 & 114 & 2 & 2 & 28 & $146 \pm 73$ \\
\hline \multicolumn{14}{|c|}{ (b) Predatory impact using detrital POC abundance } \\
\hline Month & $\begin{array}{r}\text { Abund } \\
\text { ( } \mu g \mathrm{C}\end{array}$ & $\begin{array}{l}\text { ance } \quad \% \\
\left.\mathrm{l}^{-1}\right)\end{array}$ & cleared & $\begin{array}{c}\text { Ingestion } \\
\left(\mu \mathrm{g} \mathrm{C} \mathrm{m}^{-2} \mathrm{~d}^{-1}\right)\end{array}$ & & & & & & & & & \\
\hline Dec & $843 \pm$ & 153 & 9.6 & $76920 \pm 32623$ & & & & & & & & & \\
\hline Jan & $601 \pm$ & 91 & 7.5 & $44936 \pm 23348$ & & & & & & & & & \\
\hline Feb & $407 \pm$ & 59 & 8.7 & $34862 \pm 25746$ & & & & & & & & & \\
\hline Mar & $126 \pm$ & 26 & 7.0 & $10554 \pm 5117$ & & & & & & & & & \\
\hline Apr & $671 \pm$ & 123 & 8.7 & $56290 \pm 29424$ & & & & & & & & & \\
\hline May & $592 \pm$ & & 6.7 & $41258 \pm 21268$ & & & & & & & & & \\
\hline Jun & $712 \pm$ & 142 & 9.0 & $59169 \pm 9914$ & & & & & & & & & \\
\hline Jul & $59 \pm$ & & 1.9 & $959 \pm 159$ & & & & & & & & & \\
\hline Aug & $171 \pm$ & & 3.3 & $4957 \pm 799$ & & & & & & & & & \\
\hline Sep & $48 \pm$ & & 4.2 & $2079 \pm 1119$ & & & & & & & & & \\
\hline Oct & $158 \pm$ & & 6.7 & $7356 \pm 4957$ & & & & & & & & & \\
\hline Nov & $168 \pm$ & 43 & 4.5 & $5437 \pm 3518$ & & & & & & & & & \\
\hline
\end{tabular}


(Barange \& Gili 1988, Coma et al. 1995c, Gili et al. 1998) also indicate significant ingestion of plankton communities and suspended detrital POC. Thus, in littoral ecosystems, predation by macroinvertebrates on plankton communities and suspended detrital POC should not be disregarded.

This study represents the first steps in evaluating the grazing impact of macroinvertebrates on planktonic communities and suspended detrital POC in the northwestern Mediterranean Sea, but already suggests that this impact is indeed important. However, further work on the characterization of flow speed throughout the annual cycle and on the dependence of particle intake on flow speed under natural conditions for this and other macroinvertebrate species is necessary to obtain an accurate estimate of the grazing impact of macroinvertebrates on planktonic communities and suspended detrital POC. Such studies will provide an important contribution to the understanding of the functioning of littoral marine ecosystems.

Acknowledgements. The manuscript was improved by the comments of Enric Saiz, Ken Sebens and the constructive criticism of 2 anonymous referees. We thank Emma Cebrian for her help with phytoplankton counts. Flow cytometry facility was supplied by the University of Hawai'i with the assistance of Hector Nolla. POC and DOC analyses were provided by the Scientist Technical Service (University of Barcelona) with the assistance of I. Casals, P. Fernandez and L. Balart. Support for this work was provided by a F.P.I. fellowship from 'Ministerio de Educación y Cultura (MEC)' to M.R., by a MEC research contract to R.C., by a CICYT grant PB94-0014-C0201 and by the MAST-III-ELOISE European Union METRO MED Project.

\section{LITERATURE CITED}

Akre BG, Johnson DM (1979) Switching and sigmoid functional response curves by damselfly naiads with alternative prey available. J Anim Ecol 48:703-720

Asmus RM, Asmus H (1991) Mussel beds: limiting or promoting phytoplankton? J Exp Mar Biol Ecol 148:215-232

Azam F, Fenchel T, Field JG, Gray JS, Meyer-Reil LA, Thingstad F (1983) The ecological role of water-column microbes in the sea. Mar Ecol Prog Ser 10:257-263

Barange M, Gili JM (1988) Feeding cycles and prey capture in Eudendrium racemosum (Cavolini, 1785). J Exp Mar Biol Ecol 115:281-293

Bayer FM (1961) The shallow-water Octocorallia of the West Indian region. A manual for marine biologists. Martinus Nijhoff, The Hague

Bjornsen PK (1986) Automatic determination of bacterioplankton biomass by image analysis. Appl Environ Microbiol 51:1199-1204

Bouillon J (1995) Classe des Hydrozoaires. In: Grassé PP (ed) Traité de zoologie: Cnidaires, Hydrozoaires, Scyphozoaires, Cubozoaires, Cténaires. Masson, Paris, p 29-416

Burkill PH, Edwards ES, John AWG, Sleigh MA (1993) Microzooplankton and their herbivorous activity in the northeastern Atlantic Ocean. Deep-Sea Res II 40:479-493

Campbell L, Nolla H, Vaulot D (1994) The importance of
Prochlorococcus to community structure in the central North Pacific Ocean. Limnol Oceanogr 39:954-961

Charles F, Grémare A, Amoroux JM (1996) Ingestion rates and absorption efficiencies of Abra ovata (Mollusca: Bivalvia) fed on macrophytobenthic detritus. Estuar Coast Shelf Sci 42:83-102

Coffroth MA (1984) Ingestion and incorporation of coral mucus aggregates by a gorgonian soft coral. Mar Ecol Prog Ser 17:193-199

Coma R (1994) Energy budget assessment of two benthic marine cnidarians. PhD thesis, Univ Barcelona

Coma R, Gili JM, Zabala M, Riera T (1994) Feeding and prey capture cycles in the aposymbiotic gorgonian Paramuricea clavata. Mar Ecol Prog Ser 155:257-270

Coma R, Ribes M, Zabala M, Gili JM (1995a) Reproduction and cycle of gonadal development in the Mediterranean gorgonian Paramuricea clavata. Mar Ecol Prog Ser 117: $173-183$

Coma R, Zabala M, Gili JM (1995b) Sexual reproductive effort in the Mediterranean gorgonian Paramuricea clavata. Mar Ecol Prog Ser 117:185-192

Coma R, Gili JM, Zabala M (1995c) Trophic ecology of a benthic marine hydroid Campanularia everta. Mar Ecol Prog Ser 119:211-220

Coma R, Ribes M, Gili JM, Zabala M (1998a) An energetic approach to the study of life-history traits of two modular colonial benthic invertebrates. Mar Ecol Prog Ser 162: $89-103$

Coma R, Ribes M, Gili JM, Zabala M (1998b) Growth in a modular colonial marine invertebrate. Estuar Coast Shelf Sci $47: 459-470$

Dai CF, Lin MC (1993) The effects of flow on feeding of three gorgonians from southern Taiwan. J Exp Mar Biol Ecol $173: 57-69$

DeMott WR (1990) Hunger-dependent diet selection in suspension-feeding zooplankton. In: Hughes RN (ed) Diet selection. An interdisciplinary approach to foraging behaviour. Blackwell, Oxford, p 102-123

Edler L (1979) Recommendations for marine biological studies in the Baltic sea. Phytoplankton and chlorophyll. Baltic Mar Biol 5:5-38

Fabricius KE, Benayahu Y, Genin A (1995a) Herbivory in asymbiotic soft corals. Science 268:90-92

Fabricius KE, Genin A, Benayahu Y (1995b) Flow-dependent herbivory and growth in zooxanthellae-free soft corals. Limnol Oceanogr 40:1290-1301 (Erratum Limnol Oceanogr $41: 1520$ )

Fabricius KE, Yahel G, Genin A (1998) In situ depletion of phytoplankton by an azooxanthellate soft coral. Limnol Oceanogr 43:354-356

Faunchald K, Jumars PA (1979) The diet of worms: a study of polychaete feeding guilds. Oceanogr Mar Biol Annu Rev 17:193-284

Fautin DG, Mariscal RN (1991) Cnidaria: Anthozoa. In: Harrison FW, Wesfall JA (eds) Microscopic anatomy of invertebrates, Vol 2: Placozoa, Porifera, Cnidaria, and Ctenophora. Wiley-Liss, New York, p 267-358

Fry JC (1988) Determination of biomass. In: Austin B (ed) Methods in aquatic bacteriology. Wiley and Sons, New York, p 27-72

Gaino E, Bavestrello G, Cattaneo-Vietti R, Sarà M (1994) Scanning electron microscope evidence for diatom uptake by two Antarctic sponges. Polar Biol 14:55-58

Gili JM, Ballesteros E (1991) Structure of cnidarian populations in Mediterranean sublittoral benthic communities as a result of adaptation to different environmental conditions. Oecologia Aquat 10:243-254 
Gili JM, Coma R (1998) Benthic suspension feeders: their paramount role in littoral marine food webs. Trends Ecol Evol 13:316-321

Gili JM, Ros JD (1985) Study and cartography of the benthic communities of Medes Islands (NE Spain). PSZN T: Mar Ecol 6:219-238

Gili JM, Alvà V, Coma R, Orejas C, Pagès F, Ribes M, Zabala M. Arntz W, Bouillon J, Boero F, Hughes RG (1998) The impact of small benthic passive suspension feeders in shallow marine ecosystems: the hydroids as an example Zool Verh (Leiden) 323:1-7

Hart RD (1987) Observations on calanoids diet, seston, phytoplankton-zooplankton relationships, and interferences on calanoid food limitation in a silt-laden reservoir. Arch Hydrobiol 111:67-82

Hughes RN (1979) Optimal diets under the energy maximiza tion premise: the effects of recognition time and learning Am Nat 113:209-221

Hughes RN (1980) Optimal foraging theory in the marine context. Oceanogr Mar Biol Annu Rev 18:423-481

Huntley M, Sykes P, Rohan S, Marin V (1986) Chemicallymediated rejection of dinoflagellate prey by the copepods Calanus pacificus and Paracalanus parvus: mechanism, occurrence, and significance. Mar Ecol Prog Ser 28 $105-120$

Hyman LH (1940) The invertebrates: Protozoa through Ctenophora. MacGraw-Hill, New York

Johnson AS, Sebens KP (1993) Consequences of a flattened morphology: effects of flow on feeding rates of the scleractinian coral Meandrina meandrites. Mar Ecol Prog Ser 99 $99-114$

Jorgensen CB (1966) Biology of suspension feeding. Pergamon Press, Oxford

Jørgensen CB (1975) Comparative physiology of suspension feeding. Annu Rev Physiol 37:57-59

Kana T, Glibert PM (1987) Effect of irradiances up to $2000 \mu \mathrm{E}$ $\mathrm{m}^{-2} \mathrm{~s}^{-1}$ on marine Synechococcus WH 7803-I. Growth, pigmentation, and cell composition. Deep-Sea Res 34 : $479-516$

Kinzie RA III (1973) The zonation of West Indian gorgonians. Bull Mar Sci 23:93-1.55

Klumpp DW (1984) Nutritional ecology of the ascidian Pyura stolonifera: influence of body size, food quantity and quality on filter-feeding, respiration, assimilation efficiency and energy balance. Mar Ecol Prog Ser 19:269-284

LaBarbera M (1984) Feeding currents and particle capture mechanisms in suspension feeding animals. Am Zool 24: $71-84$

Lasker HR (1981) A comparison of the particulate feeding abilities of three species of gorgonian soft coral. Mar Ecol Prog Ser 5:61-67

Lasker HR, Gottfried MD, Coffroth MA (1983) Effects of depth on the feeding capabilities of two octocorals. Mar Biol 73: $73-78$

Lehman JT (1976) The filter-feeder as an optimal forager, and the predicted shapes of feeding curves. Limnol Oceanogr 21:501-516

Leonard AB (1989) Functional response in Antedon mediterranean (Lamarck) (Echinodermata: Crinoidea): the interaction of prey concentration and current velocity on a passive suspension-feeder. J Exp Mar Biol Ecol 127 $81-103$

Leversee GJ (1976) Flow and feeding in fan-shaped colonies of the gorgonian coral, Leptogorgia. Biol Bull 151:344-356

Lewis JB (1982) Feeding behaviour and feeding ecology of the Octocorallia (Coelenterata: Anthozoa). J Zool Lond 196:371-384
Loya Y (1972) Community structure and species diversity of hermatypic corals at Eilat, Red Sea. Mar Biol 13: $100-123$

Massana R, Gasol JM, Bjørnsen PK, Blackburn N, Hagström A, Hietanen S, Hygum J, Kuparinen BHK, Pedrós-Alió C (1997) Measurement of bacterial size via image analysis of epifluorescence preparations: description of an inexpensive system and solutions to some of the most common problems. Sci Mar 61:397-407

Monger BM, Landry MR (1993) Flow cytometric analysis of marine bacteria with Hoeschst 33342. Appl Environ Microbiol 59:905-911

Montagnes DJ, Berges SJA, Harrison PJ, Taylor FJR (1994) Estimating carbon, nitrogen, protein and chlorophyll a from volume in marine phytoplankton. Limnol Oceanogr 39:1044-1060

Murdock GR (1978) Digestion, assimilation, and transport of food in the gastrovascular cavity of a gorgonian octocoral (Cnidaria, Anthozoa). Bull Mar Sci 28:354-362

Okamura B (1990) Behavioural plasticity in the suspension feeding of benthic animals. In: Hughes RN (ed) Behavioural mechanisms of food selection. Springer Verlag, Berlin, p 637-660

Pérès JM, Picard J (1964) Nouveau manuel de Bionomie benthique de la mer Méditerranée. Recl Trav Stn Mar Endoume 47:5-137

Petersen JK, Riisgárd HU (1992) Filtration capacity of the ascidian Ciona intestinalis and its grazing impact in a shallow fjord. Mar Ecol Prog Ser 88:9-17

Pile AJ, Patterson MR, Witman JD (1996) In situ grazing on plankton $<10 \mathrm{~mm}$ by the boreal sponge Mycale lingua. Mar Ecol Prog Ser 141:95-102

Pile AJ, Patterson MR, Savarese M, Chernykh VY, Fialkov VA (1997) Trophic effects of sponge feeding within Lake Baikal's littoral zone. II. Sponge abundance, diet, feeding efficiency, and carbon flux. Limnol Oceanogr 42:178-184

Platt T, Subba Rao DV, Irwin B (1983) Photosynthesis of picoplankton in the oligotrophic ocean. Nature 301: $702-704$

Porter JW (1974) Zooplankton feeding by the caribbean reefbuilding coral Monastrea cavernosa. Proc 2nd Int Coral Reef Symp 1:111-125

Pratt EM (1906) The digestive organs of the Alcyonaria and their relation to the mesogleal cell plexus. Q J Microsc Sci 49:327-362

Purcell JE, Madin LP (1991) Diel patterns of migration, feeding, and spawning by salps in the subarctic Pacific. Mar Ecol Prog Ser 73:211-217

Putt M, Stoecker DK (1989) An experimentally determined carbon volume ratio for marine 'oligotrichous' ciliates from estuarine and coastal waters. Limnol Oceanogr 34 : $1097-1103$

Randløv A, Riisgård HU (1979) Efficiency of particle retention and filtration rate in four species of ascidians. Mar Ecol Prog Ser 1:55-59

Reiswig HM (1971) Particle feeding in natural populations of three marine demosponges. Biol Bull 141:568-591

Reiswig HM (1975) Bacteria as food for temperate-water marine sponges. Can J Zool 53:582-589

Ribes M, Coma R, Gili JM (1998a) Heterotrophic feeding by gorgonian corals with symbiotic zooxanthellae. Limnol Oceanogr 43:1170-1.179

Ribes M, Coma R, Gili JM. (1.998b) Seasonal variation of in situ feeding rates by the temperate ascidian Halocynthia papillosa. Mar Ecol Prog Ser 175:201-213

Ribes M, Coma R, Gili JM (1999a) Natural diet and grazıng rate of the temperate sponge Dysidea avara (Demospon- 
giae, Dendroceratida) throughout an annual cycle. Mar Ecol Prog Ser 176:179-190

Ribes M, Coma R, Gili JM (1999b) Seasonal variations of POC DOC and the contribution of microbial communities to the live POC in a shallow near-bottom ecosystem of the northwestern Mediterranean Sea. J Plankton Res 21:1077-1100

Riisgård JK, Larsen PS (1996) Filter-feeding in marine macroinvertebrates: pump characteristics, modelling and energy cost. Biol Rev 70:67-106

Riisgărd JK, Poulsen L, Larsen PS (1996) Phytoplankton reduction in near-bottom water caused by filter-feeding Nereis diversicolor implications for worm growth and population grazing impact. Mar Ecol Prog Ser 141:47-54

Rubenstein DI, Koehl MAR (1977) The mechanism of filter feeding: some theoretical considerations. Am Nat 111 981-994

Sebens KP, Koehl MAR (1984) The feeding ecology of two subtidal rock wall zooplanktivores, Alcyonium siderium and Metridium senile. Mar Biol 81:255-271

Sebens KP, Vandersall KS, Savina LA, Graham KR (1996) Zooplankton capture by two scleractinian corals, Madracis mirabilis and Monastrea cavernosa, in a field enclosure. Mar Biol 127:303-317

Sherr EB, Sherr BF (1991) Planktonic microbes: tiny cells at the base of the ocean's food webs. Trends Ecol Evol 6: $50-54$

Simon M, Azam F (1989) Protein content and protein synthesis rates of planktonic marine bacteria. Mar Ecol Prog Ser 51:201-213

Sokal RR, Rohlf FJ (1995) Biometry. The principles and practice of statistics in biological research, 3rd edn. Freeman, New York

Sorokin YI (1991) Biomass, metabolic rates and feeding of some common reef zoantharians and octocorals. Aust J Mar Freshw Res 42:729-741

Starkweather PL, Bogdan KG (1980) Detrital feeding in natural zooplankton communities: discrimination between live and dead algal foods. Hydrobiologia 73:83-85

Stephens DW, Krebs JR (1986) Foraging theory. Princeton University Press, Princeton

Stockner JG, Antia NJ (1986) Algal picoplankton from marine

Editorial responsibility: Roger Hughes (Contributing Editor), Bangor, Gwynedd, Wales, UK and freshwater ecosystems: a multidisciplinary perspective. Can J Fish Aquat Sci 43:2472-2503

Stuart V, Klumpp DW (1984) Evidence for food-resource partitioning by kelp-bed filter feeders. Mar Ecol Prog Ser 16: $27-37$

Tenore KR, Cammen L, Findlay SEG, Phillips N (1982) Perspectives of research on detritus: do factors controlling the availability of detritus to macroconsumers depend on its source? J Mar Res 40:473-490

True MA (1970) Etude quantitative de quatre peuplements sciaphiles sur substrat rocheux dans la région marseilles. Bull Inst Océanogr (Monaco) 1410:1-48

Turner JT (1984) Zooplankton feeding ecology: contents of fecal pellets of the copepods Eucalanus pileatus and Paracalanus quasimodo from continental shelf waters of the Gulf of Mexico. Mar Ecol Prog Ser 15:27-46

Tursch B, Tursch A (1982) The soft coral commnunity on a sheltered reef quadrat at Laing island (Papua New Guinea). Mar Biol 68:321-332

Van Wambeke F, Christaki U, Gaudy R (1996) Carbon fluxes from the microbial food web to mesozooplakton. An approach in the surface layer of a pelagic area (NW Mediterranean Sea). Oceanol Acta 19:57-66

Vaulot D, Partensky F, Neveus J, Mantoura RFC, Llewellyn C (1990) Winter presence of prochlorophytes in surface waters of the northwestern Mediterranean Sea. Limnol Oceanogr 35:1156-1164

Vedel A (1998) Phytoplankton depletion in the benthic boundary layer caused by suspension-feeding Nereis diversicolor (Polychaeta): grazing impact and effect of temperature. Mar Ecol Prog Ser 163:125-132

Verity PG, Robertson CY, Tronzo CR, Andrews MG, Nelson JR, Sieracki ME (1992) Relationships between cell volume and the carbon and nitrogen content of marine photosynthetic nanoplankton. Limnol Oceanogr 37:1434-1446

Wotton RS (1992) Particulate and dissolved organic material as food. In: Wotton RS (ed) The biology of particles in aquatic systems. CRC Press, Boca Raton, p 213-261

Zamer WE (1986) Physiological energetics of the intertidal sea anemone Anthopleura elegantissima, I. Prey capture, absorption efficiency and growth. Mar Biol 92:299-314

Submitted: August 20, 1998; Accepted: February 1, 1999

Proofs received from author(s): June 11, 1999 